\title{
EXPERIMENTS ON COLLAR ROT OF GERBERA BY USING BIOCONTROL AGENTS AND FUNGICIDES IN POT CULTURE CONDITIONS
}

\section{P. SUNEETA, K. ERAIVAN ARUTKANI AIYANATHAN \& S. NAKKEERAN}

Department of Plant Pathology, Centre for Plant Protection Studies, Tamil Nadu, Agricultural University, Coimbatore, India ABSTRACT

A detailed study was done in order to know the effect of biocontrol agents and chemical fungicides under glasshouse conditions against collar rot of Gerbera caused by Sclerotium rolfsii Sacc. The pathogen was initially isolated from infected root and a crown portion of Gerbera and confirmed the identification through morphological study. The pathogen Sclerotium rolfsii was mass multiplied in sterilized sorghum grain media, which was inoculated into the potting mixture (laterite soil, sand and compost in the ratio 3:1:1) at the rate of $5 \mathrm{~g}$ of inoculum per $\mathrm{kg}$ of pot mix. Then the pots were kept in completely randomized design (CRD) arranged in 7 treatments \& 3 replications for both bio control agents and fungicides experimentation under glass-house conditions. As a result, $T_{4}$ was found to be the best bio control treatment and $T_{3}$ as best fungicidal treatment against Sclerotium rolfsii with enhanced the growth parameters like plant height, root length and no. of flowers of Gerbera.

KEYWORDS: Fungicides, Gerbera, Trichoderma, Bacillus \& Sclerotium Rolfsii

Received: Feb 21, 2017; Accepted: Jun 15, 2017; Published: Jun 15, 2017; Paper Id.: IJASRJUN201761

\section{INTRODUCTION}

In India, a number of diseases have been observed on Gerbera during past decades. Wick and Dicklow (2013) listed the following soil borne diseases in Gerbera viz., Fusarium crown rot (Fusarium solani), Fusarium root rot (Fusarium oxysporum), Phytophthora crown and root rot (Phytophthora cryptogea, Phytophthora parasitica), Pythium root rot (Pythium spp.), Rhizoctonia root and crown rot (Rhizoctonia solani) and Southern blight (Sclerotium rolfsii).

Collar rot disease in Gerbera jamesonii Bolus ex Hook records for the first time in Tamil Nadu, India caused by Sclerotium rolfsii Sacc. (Suneeta et al., 2016). It is a hasty disease caused by most destructive soil borne pathogen, Sclerotium rolfsii. This pathogen when inoculated in pots of Gerbera seedlings, $90 \%$ of the disease incidence has been observed in glass-house conditions.

Trichoderma harzianum inoculation against pathogens causing wilt and rot diseases of vanilla, Fusarium oxysporum, Rhizoctonia solani and Sclerotium rolfsii gave 90-95\% disease suppression under greenhouse experiment and was superior than Trichoderma virens and the standard (MTCC 801) in growth promotion over the control (Sandheep and Jisha, 2014). Similarly, to evaluate the application of cell-free filtrates Bacillus subtilis BMB26 on melon plants, a cotyledon test was done under greenhouse conditions by dame et al., 2015. A significant decrease was observed in disease incidence (up to 77\%) occurred in BMB26-treated melon leaves inoculated with $S$. rolfsii after 4 days postinoculation. 


\section{MATERIALS AND METHODS}

\section{Isolation of the Collar Rot Pathogen}

The pathogen was isolated from the infected crown bits which were surface sterilized by using $0.1 \%$ mercuric chloride $\left(\mathrm{HgCl}_{2}\right)$ for 30 seconds and placed onto the PDA medium amended with $100 \mu \mathrm{g} / \mathrm{ml}$ of streptomycin sulfate, then incubated at a temperature $\left(20 \pm 2^{\circ} \mathrm{C}\right)$ for 5 days.

\section{Pathogenicity Test}

The mycelium and sclerotia of the pathogen Sclerotium rolfsii were inoculated in the collar portion of 30 days old Gerbera (var. Donavan yellow) plants and maintained in the playhouse at $22 \pm 2{ }^{\circ} \mathrm{C}$. After 7 days of inoculation typical symptoms of browning and rotting were observed and the pathogen was re-isolated.

\section{Identification of the Pathogen}

The pathogen was identified based on the phenotypic characterization viz. Size, shape \& color of sclerotia and mycelium color, density \& growth.

\section{Formulation Development of Bacillus Spp}

The bacterial antagonists (Bacillus licheniformis isolate BSD1, Bacillus subtilis isolate PSB5 and Ochrobactrum spp. Isolate BSD5) were cultured in Luria Bertani medium from the stock culture maintained at $-80^{\circ} \mathrm{C}$ and incubated at room temperature $\left(28\left(2^{\circ} \mathrm{C}\right)\right.$ for $48 \mathrm{hr}$. From these plates lapful of bacteria were inoculated into $1000 \mathrm{ml}$ of $\mathrm{NB}$ which were incubated in an orbital shaker at $150 \mathrm{rpm}$ at room temperature $\left(28\left(2^{\circ} \mathrm{C}\right)\right.$ for $48 \mathrm{hr}$. These liquid biomass along were mixed with $1 \%$ glycerol $(10 \mathrm{ml})$, tween $20(10 \mathrm{ml})$ and poly vinyl pyrrolidone - $40000 \mathrm{ml} . \mathrm{wt}(10 \mathrm{~g})$ each separately. The resultant mixture was kept in a orbital shaker at 200 RPM for 5 minutes to ensure uniform blending and homogenization of the bacterial cells. Then the formulation was standardized to $10^{7} \mathrm{cfu} / \mathrm{ml}$ and was stored at $5^{\circ} \mathrm{C}$ for further study (Somasegaran and Hoben; 1985).

\section{Development of Liquid Formulation of Trichoderma Spp}

The fungal antagonists (T. harzianum strain NVTH1, T. harzianum NVTH2 and T. viride TV1) were cultured on $1000 \mathrm{ml}$ of Potato Dextrose Broth and incubated in an orbital shaker at $150 \mathrm{RPM}$ at room temperature $\left(28\left(2^{\circ} \mathrm{C}\right)\right.$ for $48 \mathrm{hr}$. Later the liquid biomass was mixed with $1 \%$ glycerol $(10 \mathrm{ml})$, tween 20 (10ml) and poly vinyl pyrrolidone $-40000 \mathrm{ml}$. wt $(10 \mathrm{~g})$ each separately. The resultant mixture was kept in a orbital shaker at 200 RPM for 5 minutes to ensure uniform blending and homogenization of the bacterial cells. Then the formulation was standardized to obtain one ml of formulation consists of $10^{6} \mathrm{cfu} / \mathrm{ml}$. The liquid formulation was stored at $5^{\circ} \mathrm{C}$ for further study (Somasegaran and Hoben, 1985).

\section{Pot Culture Experiment}

A pot culture experiment was conducted in Completely Randomized Design (CRD) to test the effect of biocontrol agents and 6 commercial fungicides viz. difenoconazole 25\% EC (Score), tebuconazole 50\% + trifloxystrobin $25 \%$ WG (Nativo), propineb 70 WP (Antracol), propioconazole 25\% EC (Tilt), tebuconazole 250 EC (Folicur) \& Fenamodon $10 \%+$ Mancozeb $50 \% \mathrm{WG}$ (Sectin) in controlling the collar rot disease and changes in growth promotion and yield parameters of Gerbera. Potting medium (laterite soil, sand and compost in the ratio 3:1:1 w/w/w) was autoclaved for $1 \mathrm{~h}$ for two consecutive days. The pathogen, Sclerotium rolfsii was mass multiplied in sorghum grain, medium and incorporated into the soil at the rate of $5 \mathrm{~g}$ per $\mathrm{kg}$ of pot mix. The Gerbera seedlings were planted in the inoculated pots. 
Table 1: Different Treatments of Biocontrol Agents against FOG under Glasshouse Conditions

\begin{tabular}{|c|c|}
\hline Treatment & Treatment Details \\
\hline $\mathrm{T}_{1}$ & $\mathrm{RD}+* \mathrm{SD}$ with $B$. tequilensis $\mathrm{PSB} 8\left(10^{7} \mathrm{cfu} / \mathrm{ml}\right) @ 5 \mathrm{ml} / \mathrm{litre}$ \\
\hline $\mathrm{T}_{2}$ & RD + *SD with B. subtilis PSB5 (107cfu/ml) @ 5ml/litre \\
\hline $\mathrm{T}_{3}$ & $\mathrm{RD}+* \mathrm{SD}$ with $B$. amyloliquefaciens $\mathrm{PSB} 6\left(10^{7} \mathrm{cfu} / \mathrm{ml}\right) @ 5 \mathrm{ml} / \mathrm{litre}$ \\
\hline $\mathrm{T}_{4}$ & RD + *SD with T. harzianum NVTH2 (10 6 cfu/ml) @ 5ml/litre \\
\hline $\mathrm{T}_{5}$ & RD + *SD with T. viride TV1 (10 $\mathrm{cfu} / \mathrm{ml}) @ 5 \mathrm{ml} /$ litre \\
\hline $\mathrm{T}_{6}$ & RD + *SD with Carbendazim 50\%WP @ 1ml/litre \\
\hline $\mathrm{T}_{7}$ & Control \\
\hline
\end{tabular}

RD-Root Dip at planting; SD-Soil Drenching; * Soil Drenching given at 15 days interval

Table 2: Different Treatments of Fungicides against FOG under Glasshouse Conditions

\begin{tabular}{|c|c|}
\hline Treatment & Treatment Details \\
\hline $\mathrm{T}_{1}$ & RD + *SD with Tebuconazole 250EC @ 1ml/litre \\
\hline $\mathrm{T}_{2}$ & RD + *SD with Tebuconazole 50\%+Trifloxystrobin 25\%WG @ 1ml/litre \\
\hline $\mathrm{T}_{3}$ & RD + *SD with Propioconazole 25\%EC @ 1ml/litre \\
\hline $\mathrm{T}_{4}$ & RD + *SD with Propineb 70WP @ 1ml/litre \\
\hline $\mathrm{T}_{5}$ & RD + *SD with Fenamidone 10\%+ Mancozeb 50\% WG @ 1ml/litre \\
\hline $\mathrm{T}_{6}$ & RD + *SD with Difenoconazole 25\%EC @ 1ml/litre \\
\hline $\mathrm{T}_{7}$ & Control \\
\hline
\end{tabular}

RD-Root Dip at planting; SD-Soil Drenching; * Soil Drenching given at 15 days interval

The collar rot incidence by Sclerotium rolfsii in Gerbera was recorded and expressed as percentage of disease incidence. Plant height and root length were recorded at monthly interval until harvesting. Flowering started after 30 days of transplanting and yield was recorded till the end.

\section{Statistical Analysis}

All the experiments were statistically analyzed independently. The treatment means were compared by Duncan's Multiple Range-Test (DMRT) (Gomez and Gomez, 1984). The package used for analysis was IRRISTAT version 92-1 developed by the International Rice Research Institute, Biometrics unit, The Philippines.

\section{RESULTS AND DISCUSSIONS}

\section{Symptomatology of Collar Rot}

The collar rot symptom was noticed both in seedling and maturity stage. Initially, the infected plants exhibited brown necrotic lesions on the petioles near collar region. Subsequently, the leaves turned water soaked to brown colored. The affected leaves droop and resulted in the death of the infected plants. The typical symptom observed was the presence of a cottony, white, dense mat of mycelial growth on the surface of the petioles and collar region and on the adjacent soil surface. These bodies turned brown and hard as they mature and formed sclerotia. The fungus $S$. rolfsii induced a variety of symptoms such as seed rots, seedling blight, collar rot, stem rot, wilt in different host plants (Arunasri et al., 2011).

\section{Pathogenicity}

Inoculation of 5 sclerotia of $S$. rolfsii in to the collar region of 30 days old healthy Gerbera variety Bellwater (White) expressed the typical symptoms within 7 days after inoculation. Infected plants showed typical rot in the collar portion with numerous brown, mustard seed like sclerotia, followed by blightening and girdling of the affected plants. The pathogen was reisolated from the artificially inoculated plants and showed all the characteristic features of the original culture. Thus Koch's postulate was confirmed. The similar methodology was followed and proven pathogenicity in tomato plants by Xie et al. 
(2014).

\section{Morphological Characterization}

Pathogen associated with collar rot was isolated from Gerbera variety Donavan (yellow). The mycelium of the fungal culture on PDA medium was white and fluffy. Small white tufts were formed on mycelium which later turned to dark brown round sclerotia and measured 1-2 $\mathrm{mm}$ in diameter. Based on phenotypic characters, the pathogen was confirmed as Sclerotium rolfsii. Similar observations were reported by Reddi Kumar et al. (2014) in Groundnut.

\section{Glass-house Trial of Biocontrol Agents on Collar Rot Incidence and Growth Parameters of Gerbera}

Trichoderma harzianum NVTH2 $\left(\mathrm{T}_{4}\right)$ was found to be the best treatment in reducing the collar rot incidence $(39.18 \%)$ and growth promotion of Gerbera $(40.21 \mathrm{~cm}$ plant height and $21.26 \mathrm{~cm}$ root length) among all the treated biocontrol agents followed by Trichoderma viride TV1 $\left(\mathrm{T}_{5}\right)$ over the control. Moreover, Bacillus subtilis PSB5 ( $\left.\mathrm{T}_{2}\right)$ was found to be significantly different between antagonistic Bacillus strains which increased the yield (8.21) and decreased the collar rot incidence $(44.21 \%)$ over the control (Table 3$)$.

Seed treatment of Trichoderma viride recorded the maximum root rot incidences (21.4\%) in black gram incited by Macrophomina phaseolina followed by Trichoderma harzianum (26.6\%). The maximum seed germination (75\%), shoot length $(43.2 \mathrm{~cm})$ and root length $(16.0 \mathrm{~cm})$ was recorded in the same seed treatment of Trichoderma viride followed by Trichoderma harzianum under glass-house conditions (Karthikeyan et al., 2015). The reduction of root-rot of bean (Sclerotium rolfsii) was the highest in the seeds pre-treated with the isolates B. subtilis ssp. spizizenii, B. subtilis ssp. subtilis, B. atrophaeus, B. tequilensis and S. cyaneofuscatus, which resulted in 50-58.5\% reduction in severity of the disease root-rot. Also, all the isolates except $S$. acrimycini and S. flavofuscus significantly increased the root and shoot length, the fresh weight root, stem and leaves $(\mathrm{p}<0.05)$ as well as the dry weight root, stem, leaves and volume root bean seedlings compared with the positive control with $S$. rolfsii (Gholami et al., 2014).

Table 3: Effect of Biocontrol Agents on Collar rot Incidence and Growth Parameters of Gerbera under Glasshouse Conditions

\begin{tabular}{|l|l|c|c|c|c|}
\hline S. No. & \multicolumn{1}{|c|}{ Treatment Schedule } & $\begin{array}{c}\text { Wilt } \\
\text { Incidence* }(\%)\end{array}$ & $\begin{array}{c}\text { Plant Height* } \\
(\mathbf{c m})\end{array}$ & $\begin{array}{c}\text { Root } \\
\text { Length* } \\
(\mathbf{c m})\end{array}$ & $\begin{array}{c}\text { No. of } \\
\text { Flowers/Plant* }\end{array}$ \\
\hline $\mathrm{T}_{1}$ & RD+SD*-B. tequilensis PSB8 & $45.16^{\mathrm{e}}(48.78)$ & $38.62^{\mathrm{c}}$ & $19.11^{\mathrm{c}}$ & $7.28^{\mathrm{c}}$ \\
\hline $\mathrm{T}_{2}$ & RD+SD*-B. subtilis PSB5 & $44.21^{\mathrm{d}}(49.85)$ & $39.92^{\mathrm{b}}$ & $19.81^{\mathrm{c}}$ & $8.31^{\mathrm{b}}$ \\
\hline $\mathrm{T}_{3}$ & $\begin{array}{l}\text { RD+SD*-B. amyloliquefaciens } \\
\text { PSB6 }\end{array}$ & $47.73^{\mathrm{f}}(45.86)$ & $37.10^{\mathrm{d}}$ & $18.33^{\mathrm{d}}$ & $6.03^{\mathrm{d}}$ \\
\hline $\mathrm{T}_{4}$ & RD+SD*-T. harzianum NVTH2 & $39.18^{\mathrm{a}}(55.56)$ & $40.21^{\mathrm{a}}$ & $21.26^{\mathrm{a}}$ & $9.67^{\mathrm{a}}$ \\
\hline $\mathrm{T}_{5}$ & RD+SD*-T. viride TV1 & $40.63^{\mathrm{b}}(53.91)$ & $39.11^{\mathrm{b}}$ & $20.11^{\mathrm{b}}$ & $9.23^{\mathrm{a}}$ \\
\hline $\mathrm{T}_{6}$ & $\begin{array}{l}\text { RD+SD*Carbendazim 50\%WP } \\
\text { @ } 1 \mathrm{ml} / \text { litre }\end{array}$ & $42.10^{\mathrm{c}}(52.00)$ & $39.27^{\mathrm{b}}$ & $19.32^{\mathrm{c}}$ & $8.91^{\mathrm{b}}$ \\
\hline $\mathrm{T}_{7}$ & Control & $88.17^{\mathrm{g}}$ & $36.16^{\mathrm{e}}$ & $17.60^{\mathrm{e}}$ & $5.56^{\mathrm{e}}$ \\
\hline
\end{tabular}

*Values are mean of three replications.

In a column, means followed by a common letter are not significantly different at the 5\% level by DMRT Values in parentheses are percent inhibition over control (\%).

Likewise, among 6 different commercial fungicide treatments, Propioconazole 25\%EC (Tilt) and Tebuconazole $50 \%+$ Trifloxystrobin $25 \%$ WG (Nativo) were found to be highly significant in reducing the collar rot disease upto $30-35 \%$ and promoted the growth parameters like plant height, root length \& yield of Gerbera. The other fungicides like 
Tebuconazole 250EC (Score), Fenamidone 10\%+ Mancozeb 50\% WG (section) Propineb 70WP (antracol) were significantly different and found to be effective against Sclerotium rolfsii (Table 4).

Application of Mancozeb, Thiphanate-methyl, Tebuconazole against collar rot of chickpea (Sclerotium rolfsii) significantly reduced plant mortality from $50 \%$ to $95 \%$ over positive control in pot trial. As a result, there was $233 \%$ and $33 \%$ to $67 \%$ increase in biomass of shoot and root over positive control, respectively (Khan and Javaid, 2015).

Table 4: Effect of Fungicides on Collar Rot Incidence and Growth Parameters of Gerbera under Glasshouse Conditions

\begin{tabular}{|l|l|c|c|c|c|}
\hline S. No. & \multicolumn{1}{|c|}{ Treatment Schedule } & $\begin{array}{c}\text { Wilt } \\
\text { Incidence*(\%) }\end{array}$ & $\begin{array}{c}\text { Plant } \\
\text { Height* } \\
(\mathbf{c m})\end{array}$ & $\begin{array}{c}\text { Root } \\
\text { Length* } \\
(\mathbf{c m})\end{array}$ & $\begin{array}{c}\text { No. of } \\
\text { Flowers/Plant* }\end{array}$ \\
\hline $\mathrm{T}_{1}$ & RD+SD*-Tebuconazole 250EC & $36.26^{\mathrm{c}}(59.39)$ & $39.80^{\mathrm{b}}$ & $18.45^{\mathrm{b}}$ & $10.11^{\mathrm{c}}$ \\
\hline $\mathrm{T}_{2}$ & $\begin{array}{l}\text { RD+SD*- Tebuconazole 50\%+ } \\
\text { Trifloxystrobin 25\%WG }\end{array}$ & $33.16^{\mathrm{a}}(62.87)$ & $40.51^{\mathrm{a}}$ & $19.26^{\mathrm{a}}$ & $12.20^{\mathrm{a}}$ \\
\hline $\mathrm{T}_{3}$ & RD+SD*- Propioconazole 25\%EC & $35.15^{\mathrm{b}}(60.64)$ & $39.12^{\mathrm{c}}$ & $18.61^{\mathrm{b}}$ & $11.34^{\mathrm{b}}$ \\
\hline $\mathrm{T}_{4}$ & RD+SD*- Propineb 70WP & $40.60^{\mathrm{e}}(54.54)$ & $37.61^{\mathrm{e}}$ & $17.88^{\mathrm{c}}$ & $8.12^{\mathrm{e}}$ \\
\hline $\mathrm{T}_{5}$ & $\begin{array}{l}\text { RD+SD*-Fenamidone 10\%+ } \\
\text { Mancozeb 50\% WG }\end{array}$ & $39.32^{\mathrm{d}}(55.97)$ & $38.70^{\mathrm{d}}$ & $18.43^{\mathrm{b}}$ & $9.36^{\mathrm{d}}$ \\
\hline $\mathrm{T}_{6}$ & RD+SD*-Difenoconazole 25\%EC & $42.23^{\mathrm{f}}(52.71)$ & $36.83^{\mathrm{f}}$ & $17.66^{\mathrm{c}}$ & $7.23^{\mathrm{f}}$ \\
\hline $\mathrm{T}_{7}$ & Control & $89.31^{\mathrm{g}}$ & $35.72^{\mathrm{g}}$ & $16.23^{\mathrm{d}}$ & $5.66^{\mathrm{g}}$ \\
\hline
\end{tabular}

*Values are mean of three replications.

In a column, means followed by a common letter are not significantly different at the 5\% level by DMRT Values in parentheses are percent inhibition over control (\%).

\section{CONCLUSIONS}

The extensive study on pot cultures of a Gerbera was done to study the efficiency of biocontrol agents (Bacillus spp. And Trichoderma spp.) and 6 commercial fungicides towards the disease management of collar rot caused by Sclerotium rolfsii and growth promotion activity in Gerbera. The Trichoderma harzianum (NVTH2) was found to be a most efficient biocontrol agent and all the 6 commercial fungicides treated were found to be highly inhibitory on deadly pathogen Sclerotium rolfsii.

\section{ACKNOWLEDGEMENT}

I would like to reveal my thanks to the chairman, Prof. K. Eraivan Arutkani Aiyanathan and special thanks for the encouragement provided by Prof. Dr. S. Nakkeeran and Assistant Prof. Dr. P. Renukadevi. I would also like to acknowledge the Department of Plant Pathology, Tamil Nadu Agricultural University, India and Indian Council of Agricultural Research (ICAR) for providing Junior Research Fellowship (JRF).

\section{REFERENCES}

1. Wick, R. and Dicklow, B. 2013. Diseases of African Daisy (Gerbera jamesonii H. Bolus ex J. D. Hook). Scientia Agraria Curitiba., 9(4):481-489.

2. Suneeta, P., Eraivan, A.A.K., Nakkeeran, S. 2016. First report of collar rot disease in Gerbera jamesonii Bolus ex Hook caused by Slerotium rolfsii Sacc. in India. Int. J. of research in Applied, Natural and Social sciences, 4(10):97-100.

3. Sandheep, R. A. and Jisha, M. S. 2014. Screening and identification of potential Trichoderma sp.against soil borne pathogens of Vanilla (Vanilla planifolia). Indian J. Agric. Res.., 48 (6) 459-464. 
4. Darma, R., Purnamasari, M., Agustina, D., Pramudito, E. T., Sugiharti, M. and Suwanto, A. 2016. A strong antifungalproducing Bacteria from Bamboo Powder for Biocontrol of Sclerotium rolfsii in Melon (Cucumis melo var. amanta). J Plant Pathol Microbiol; 7(2): 334. doi:10.4172/2157-7471.1000334

5. Somasegaran, P. and Hoben, H. J. 1985. Methods in legume Rhizobium technology, University of Hawaii, NiFTAL Project and Mircen. Department of Agronomy and Soils,; pp 451.

6. Gomez, K. A. and Gomez, A. A. 1984. Statistical Procedure for Agricultural Research.; John Wiley and Sons, New York.

7. Arunasri, P., Chalam, T. V., Reddy, N. P. E. and Reddy, S. T., 2011. Collar rot disease of Crossandra induced by Sclerotium rolfsii and its management: a critical review. International J. of Applied biology and Pharmaceutical technology., 2 (2): 307.

8. Xie, C., Huang, C. H. and Vallad, E. G. 2014. Mycelial Compatibility and Pathogenic Diversity Among Sclerotium rolfsii Isolates in the Southern United States. Plant Disease: 98(12): 1685-1694.

9. Reddi Kumar, M., Madhavi Santhoshi, V. M., Giridhara Krishna, T. and Raja Reddy, K. 2014. Cultural and Morphological Variability Sclerotium rolfsii Isolates Infecting Groundnut and Its Reaction to Some Fungicidal. Int.J.Curr.Microbiol.App.Sci; 3(10): 553-561.

10. Karthikeyan, V., Brinda, S., Annadurai, B. and Gangwar, S. K. 2015. Biological control of Macrophomina phaseolina (Tassi) Goid root rot in Vigna mungo (black gram) with Trichoderma spp. Int. J. of advanced biological Research; 5(2): 118-127.

11. Gholami, M., Khakvar, R. and Niknam, G. 2014. Introduction of some new endophytic bacteria from Bacillus and Streptomyces genera as successful biocontrol agents against Sclerotium rolfsii.Archives of Phytopathology and Plant Protection, 47(1): 122-130.

12. Khan, H.I. and Javaid, A. 2015. Chemical control of Collar rot disease of chickpea. Pak. J. Phytopathol.; 27 (01): 61-68. 